\title{
Desseriação Escolar: Alternativa para o Sucesso?
}

\author{
Candido Alberto Gomes*
}

\section{Resumo}

Este trabalho é uma pesquisa de pesquisas que tem em vista efetuar um balanço das experiências de desseriação escolar no ensino fundamental do Brasil, nos últimos 15 anos, buscando resposta, entre outras à indagação sobre se tais experiências têm contribuído para melhorar o desempenho dos alunos ou, ao contrário, à queda de aproveitamento discente. Para tanto foram selecionadas e analisadas 62 pesquisas nacionais, com diferentes enfoques teóricos e metodológicos. Os resultados mostram que diferentes experiências de desseriação apresentam riscos e desvantagens, entre elas a quebra do cha-

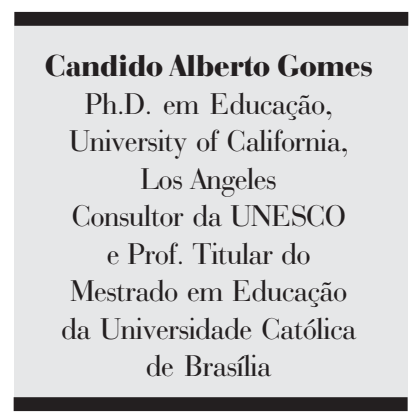

mais resistências quanto mais tentam modificar os códigos educacionais. As pesquisas de maior porte não encontram evidências de que a desseriação rebaixe significativamente $\mathrm{o}$ aproveitamento discente, mas também não apresentam indicações de que a mesma o eleve. As experiências internacionais mostram que os países onde a promoção automática é adotada, o aluno é cercado de cuidados para elevar a sua aprendizagem, enquanto, por outro lado, a reprovação se revela uma expressão cultural. As conclusões indicam que o risco da desseriação insiste em contentar-se com a melhoria da eficiência e a redução dos custos, por meio da correção do fluxo discente, mantendo baixos níveis de qualidade e eqüidade.

Palavras-chave: Ensino fundamental. Repetência. Ciclos. Aceleração da aprendizagem. Progressão continuada. Democratização da educação. Educação comparada.

\footnotetext{
* O autor agradece a colaboração de Myriam Christiano Maia Gonçalves e Alda Lino dos Santos Pereira, mestrandas em educação da Universidade Católica de Brasília, bem como o inestimável apoio da UNESCO e da Universidade Católica de Brasília, bem como a atuação do Sistema de Bibliotecas desta Universidade e da Biblioteca da UNESCO. Este trabalho se baseia em relatório apresentado ao Seminário Internacional sobre Desseriação do Ensino Fundamental, realizado pela UNESCO, MEC e UCB (GOMES, 2003).
} 


\title{
Desseriação Escolar: Alternativa para o Sucesso?
}

\author{
Candido Alberto Gomes*
}

\section{Resumo}

Este trabalho é uma pesquisa de pesquisas que tem em vista efetuar um balanço das experiências de desseriação escolar no ensino fundamental do Brasil, nos últimos 15 anos, buscando resposta, entre outras à indagação sobre se tais experiências têm contribuído para melhorar o desempenho dos alunos ou, ao contrário, à queda de aproveitamento discente. Para tanto foram selecionadas e analisadas 62 pesquisas nacionais, com diferentes enfoques teóricos e metodológicos. Os resultados mostram que diferentes experiências de desseriação apresentam riscos e desvantagens, entre elas a quebra do cha-

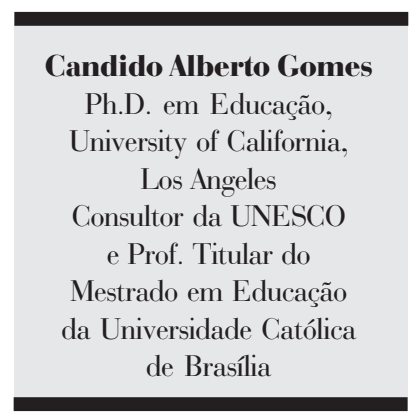

mais resistências quanto mais tentam modificar os códigos educacionais. As pesquisas de maior porte não encontram evidências de que a desseriação rebaixe significativamente $\mathrm{o}$ aproveitamento discente, mas também não apresentam indicações de que a mesma o eleve. As experiências internacionais mostram que os países onde a promoção automática é adotada, o aluno é cercado de cuidados para elevar a sua aprendizagem, enquanto, por outro lado, a reprovação se revela uma expressão cultural. As conclusões indicam que o risco da desseriação insiste em contentar-se com a melhoria da eficiência e a redução dos custos, por meio da correção do fluxo discente, mantendo baixos níveis de qualidade e eqüidade.

Palavras-chave: Ensino fundamental. Repetência. Ciclos. Aceleração da aprendizagem. Progressão continuada. Democratização da educação. Educação comparada.

\footnotetext{
* O autor agradece a colaboração de Myriam Christiano Maia Gonçalves e Alda Lino dos Santos Pereira, mestrandas em educação da Universidade Católica de Brasília, bem como o inestimável apoio da UNESCO e da Universidade Católica de Brasília, bem como a atuação do Sistema de Bibliotecas desta Universidade e da Biblioteca da UNESCO. Este trabalho se baseia em relatório apresentado ao Seminário Internacional sobre Desseriação do Ensino Fundamental, realizado pela UNESCO, MEC e UCB (GOMES, 2003).
} 
A repetência, um dos sintomas em que se traduz o fracasso escolar, é fenômeno de grandes proporções, aparentemente em declínio no mundo. Essa endemia, conforme salientado por um relatório (AMADIO, 1996), se choca com a mensagem de Jomtien, segundo a qual todas as crianças podem aprender. E se coloca, portanto, como um grande obstáculo diante dos compromissos da Educação para Todos, que envolvem a democratização da educação de qualidade, em que a escola não pode ser uma usina de insucesso, mas uma instituição que atenda às necessidades de aprendizagem.

Esse complexo desafio não tem respostas simples. Dentre elas, a Lei de Diretrizes e Bases (BRASIL, 1996), que recepcionou expressamente a Declaração Mundial de Educação para Todos, sem impor formulários, mas respeitando experiências prévias, facultou à educação básica organizar-se em "séries anuais, períodos semestrais, ciclos, alternância regular de períodos de estudos, grupos não-seriados, com base na idade, na competência e em outros critérios, ou por forma diversa de organização, sempre que o interesse do processo de aprendizagem assim o recomendar". Com base nesse dispositivo, avançaram experiências de desseriação, como alternativa à organização escolar, entre elas a formação de ciclos e a aceleração da aprendizagem. A experiência acumulada no País hoje é de tal ordem que urge resenhar as pesquisas realizadas sobre o assunto para se dimensionar luzes e sombras, vantagens e desvantagens de alternativas que têm sido seguidas. Certamente perguntas difíceis raramente recebem respostas fáceis e indisputáveis.

\section{Uma Visão Internacional}

A literatura internacional oferece um panorama pouco favorável à reprovação, embora lance algumas dúvidas, o que, em prin- cípio, poderia corroborar políticas brasileiras. Com efeito, algumas das mais abrangentes resenhas da literatura não situam a reprovação como um fator de grande impacto positivo sobre o rendimento discente. Segundo Schiefelbein e Simmons (1980), a repetência está associada ao baixo desempenho, de tal modo que, quanto mais vezes o aluno repete, menores são os seus escores. Rocha (1983), por sua vez, não encontrou evidências de que a repetência seja mais efetiva que a promoção: nem a repetência leva a melhores padrões, nem a promoção automática baixaria esses padrões (OAKES; LIPTON, 1990). No entanto, a promoção automática, desacompanhada de ações suplementares não meIhora as condições para o sucesso, ao contrário, tende a manter tudo como dantes ou pior que dantes no quartel de Abrantes. Em outros termos, se a reprovação por si só piora o rendimento, a promoção automática também não o melhora. Isso posto, se a questão for a de manter basicamente o mesmo nível qualitativo da educação, a eliminação da reprovação conduz a eventuais melhorias, além de corrigir o fluxo discente, o que tem grandes repercussões sobre os custos. Caso, entretanto, se colocar a exigência de melhorar de modo substancial o nível qualitativo da educação, em países e regiões de baixo rendimento discente, a promoção tem efeitos débeis, havendo necessidade de um conjunto de medidas de apoio.

Eisemon (1997), por sua vez, verificou que certos países reprovam muito mais que outros, denotando ausência de padrões objetivos e critérios explícitos de promoção, o que constitui obstáculo à melhoria da qualidade e da democratização. Mais ainda, as constatações contraditórias sobre a repetência denotam que os sistemas educacionais variam enormemente em termos de incidência, causas e conseqüências da 
repetência e, mais ainda, que níveis altos e baixos de repetência têm causas sistêmicas. Assim, pode-se falar em culturas da repetência, o que é compreensível pelo enraizamento da educação nas sociedades e nas culturas. Por isso mesmo, Orivel e Orivel (1999), encarando do ponto de vista econômico, não vêem a aprovação/reprovação como um indicador de eficiência interna dos sistemas educacionais. Pelas variações observadas, concluem que a repetência tem a ver com fatores culturais e históricos e não com a competência. No entanto, as constatações indicam que os sistemas que mais reprovam são os que têm maior abandono, este, sim, constituindo indicador de eficiência interna.

Crahay (1996), numa fina análise dos países da União Européia, chega, por seu lado, a conclusões muito interessantes:

- As evidências de pesquisa indicam que as provas aplicadas pelos professores ampliam a dispersão do rendimento em relação aos testes padronizados. Dessa forma, sua avaliação amplifica a heterogeneidade e situa grupos consideráveis de alunos abaixo do rendimento mínimo, de tal forma que o insucesso está relacionado à turma do aluno, isto é, aqueles que são reprovados numa turma poderiam ser aprovados noutra e vice-versa.

- Os professores tendem a reprovar os mais "fracos" da turma, ainda que tenham realizado progressos expressivos, pois utilizam avaliação com referência à norma (isto é, comparam os alunos uns com os outros). Além disso, a avaliação dos alunos para os docentes é questão de credibilidade profissional em face dos colegas.

- A retenção se pratica em silêncio. Os docentes pouco explicam as razões das retenções e os alunos não sa- bem por que nem onde devem melhorar. Com isso não é de admirar que as notas dos alunos retidos, quando melhoram, depois de um ano deixam de apresentar diferenças expressivas.

- Se a ameaça de insucesso seria o motor dos trabalhos dos alunos, para que tal ameaça seja credível, é necessário que atinja constantemente certo número de alunos.

- Por fim, não foram encontradas relações entre os resultados das pesquisas do IEA e o fato de haver promoção automática ou não nos diversos países. Aqueles países que têm menor retenção não têm necessariamente menor rendimento e os que têm maior retenção não têm necessariamente maior rendimento.

Todavia, afirma Crahay (1996), eliminar a retenção representa um processo revolucionário. $\bigcirc$ funcionamento da escola não se concebe sem a adesão dos seus membros e utilizadores, por meio de um contrato social. Se, para os atores de um país, a escola funciona com base na retenção, é preciso que passem a dar sentido a uma escola que tem como motor o desenvolvimento de conhecimentos e competências. Esse contrato social, pode-se dizer, é a base das culturas que valorizam a repetência de formas e em proporções diferenciadas.

Numa posição de prudência, precisa-se considerar que nem tudo são flores do lado da promoção automática. Se, por um lado, a reprovação, segundo a literatura, traz mais malefícios que benefícios, ela pode render resultados positivos quando os alunos retidos recebem atenção especial. Segundo Snow, Burns e Griffin (1998), na ausência de outras evidências de pesquisa, não é de bom senso 
determinar que seja totalmente banida a prática da retenção no início da escolarização. Isso decorre da grande importância da alfabetização, sobretudo a leitura, para todas as séries posteriores, embora o valor da retenção como prática para prevenir dificuldades de leitura não tenha sido ainda amplamente demonstrado. Nesse caso, o apoio educativo adicional, no caso de retenção, faz maior diferença que o aumento do tempo de ensino. De qualquer modo, quanto mais cedo forem resolvidos os problemas de leitura, melhor (é o que cumpre evitar a todo custo). Os autores insistem na relação entre o aproveitamento e medidas de apoio ou, quando a escola apresenta baixo desempenho, a própria reestruturação da escola.

Um alerta mais preocupante parte de pesquisa avaliativa do Institut de Recherche sur l'Économie de l'Éducation (IREDU) sobre um programa de recuperação de deficiências de aprendizagem ao fim do ensino primário no departamento de Haute-Marne, França (PIQUÉE; SUCHAUT, 2002). Tal programa visava a reduzir as desigualdades de aprendizagem, inclusive recuperando habilidades de alfabetização, e consistia em trabalhar várias horas por semana com reduzidos grupos de alunos que apresentavam grandes dificuldades e se encontravam em situação precoce de rejeição da escola. Os resultados se revelaram desapontadores, podendo-se inferir que a intervenção ocorresse demasiado tarde. Portanto, é alto o custo de não dominar a alfabetização na época própria, indicando que as desigualdades de aproveitamento devem ser atacadas desde cedo, em vez de adiar o seu enfrentamento.

Eisemon (1997) também se refere aos riscos da promoção automática, como, por exemplo, na Costa Rica e Venezuela, onde os níveis de reprovação só se reduziram pela metade porque os professores desenvolveram estratégias de não promover os alunos, driblando as normas oficiais. Amadio (1996), também referindo-se à América Latina, afirma que a promoção automática não assegura melhor aprendizagem ou a eliminação da repetência. Na ausência de outras medidas ela pode servir apenas para transferir os problemas para o fim do ciclo básico. Como, inclusive, a promoção automática pode representar níveis diferentes de exigências para diferentes grupos sociais - sendo, obviamente, menos exigentes para os menos favorecidos -, as estratégias para o combate à repetência e ao fracasso escolar em geral devem ser de largo escopo e compreensivas, nunca tópicas e restritas, sob pena de se efetuarem mudanças meramente estatísticas. Para tanto, considerando que os pobres se incluem nos grupos de risco, tendem a ser bem sucedidas intervenções focalizadas em tais grupos, inclusive as indiretas, como de saúde escolar e nutrição (WINKLER, 2000). Nesse sentido - e em face das agudas desigualdades sociais no Continente - é preciso considerar as condições de aprendizagem não apenas das crianças de baixa renda, mas a distância entre as condições de pobres e não pobres, de modo a reduzir a distância entre elas. Ademais, a política educacional deve voltar-se para os três processos nucleares que explicam as crescentes desigualdades: desigualdades dentro e fora do sistema educacional e desigualdades resultantes da interação entre o sistema educacional e o seu contexto. Nesse sentido, uma seqüência possível de ciclos de políticas consistiria em equalizar os insumos, tornar a utilização de insumos mais progressiva e desenvolver estratégias diferentes para as crianças socialmente menos privilegiadas (REIMERS, 2000). 
Em suma, a promoção automática é atraente pelos seus apelos e possibilidades, entretanto, seus efeitos podem ser regressivos se não for utilizada com cuidado e, em especial, no âmbito de um conjunto de medidas para combater o fracasso escolar e reduzir as desigualdades. Para isso a questão fundamental não é reprovar ou deixar de reprovar, porém melhorar as condições de aprendizagem de todos, notadamente dos menos favorecidos.

\section{Balanço Parcial de Experiências Brasileiras}

As experiências brasileiras de desseriação de modo geral corroboram a literatura internacional: a reprovação não parece melhorar o aproveitamento, antes o conduz a uma queda cada vez maior, à medida que amplia a distorção idade-série. As diversas formas de desseriação, como os ciclos e a progressão continuada, fugindo ao modelo ortodoxo de promoção ou retenção ao fim de cada série anual, não leva o rendimento à queda livre. $\bigcirc$ aproveitamento se mantém em níveis estatisticamente significativos, o que constitui um desafio: a desseriação também não parece estar resolvendo a necessidade de aumentar o rendimento. Ao sair dos grandes levantamentos para a pesquisa naturalística e abrir as caixas pretas da escola e da sala de aula, deparamo-nos com reinterpretações, distorções e resistências que resultam do rompimento do contrato social a que Crahay (1996) se refere.

Os trabalhos de pesquisa sobre o Brasil foram selecionados a partir de bases eletrônicas de dados, levantamentos em bibliotecas e indicações bibliográficas e citações realizadas pelos diversos materiais
(SOUSA et al., 2003). De modo geral poucos são os projetos avaliativos amplos. As pesquisas são muitas vezes pontuais, dentro das possibilidades de trabalhos acadêmicos, e concentradas nas regiões mais desenvolvidas, que foram, por isso mesmo, as que tomaram a dianteira dessas inovações e são também as melhor documentadas. Predominam os estudos de caso e as análises de dados agregados. No primeiro caso, ganha-se em profundidade e compreensão, porém a generalizabilidade é limitada. O levantamento não exaustivo permitiu selecionar 62 pesquisas brasileiras, das quais 34 constituíram o "núcleo duro" desta pesquisa das pesquisas.

Os primeiros resultados, negativos, se referem ao sistema de avanços progressivos em Santa Catarina, com a promoção automática, que veio a ser extinto. Seguemse várias pesquisas sobre São Paulo. Os resultados são mistos, ora acusando aprovação, retenção e evasão menores antes que depois da implantação do Ciclo Bási$c o$, enquanto outras pesquisas, analisando períodos mais longos, encontraram benefícios na promoção. No entanto, com a sombra da seriação mantida pelos professores por trás dos ciclos, diversas distorções foram constatadas: a transferência do primeiro pico de reprovação para o fim do Ciclo Básico e para a quinta série, a definição dos conteúdos curriculares do Ciclo Básico pelos professores das séries posteriores, a redução das taxas de repetência ao fim da primeira, mas não da segunda série e o acréscimo de evadidos entre a segunda e a terceira séries (ALAVARSE, 2002; GOMES, 2003). Apesar desses resultados, o Ciclo Básico não foi abandonado, mas teve a sua experiência ampliada, vindo a desembocar, com novas características, na 
progressão continuada. Estabeleceu-se uma rara continuidade, pela qual pelo menos um relatório, apesar de reconhecer os graves percalços da experiência, recomenda que ela seja alargada ainda mais.

Caso de Minas Gerais no início dos anos 90 foi objeto de uma grande avaliação externa. Os resultados mostram que, em grande parte, o Ciclo Básico de Alfabetização alcançava os seus objetivos (VIANNA, 1992). Embora a aprendizagem fosse realizada pela maior parte dos alunos, havia problemas críticos na expressão escrita e na aplicação de noções básicas de Matemática. Além disso, metade das crianças seguia fluxo normal com relação à idadesérie, o que indicava avanço significativo. Longe de ser uma ilha num oceano de dificuldades, o Ciclo Básico de Alfabetização enfrentava a falta de recursos didáticos adequados, padecia da falta de valorização do magistério e, apesar de todas as discussões, desde o início, muitas escolas consideravam a proposta impositiva.

Paraná foi objeto de análises em parte conflitantes. Uma verificou maior fluidez entre a primeira e a segunda séries, além de melhoria do fluxo e redução do desperdício com a reprovação. Outra encontrou resultados modestos na retenção, aprovação e evasão. Também se assinalou a transferência de problemas do Ciclo Básico de Alfabetização para as séries posteriores, fato que não é incongruente com o incremento da fluidez entre a primeira e a segunda séries. Em contraste, uma avaliação recente focalizou a ulterior adoção dos ciclos ao longo de todo o ensino fundamental, baseada em testes de rendimento especialmente de ciências na quarta e oitava séries. Os resultados mostram ligeira vantagem, pos- sivelmente insignificante ante os valores dos desvios padrões, das médias dos alunos na organização em ciclos, comparados com os do regime seriado. No entanto, a reprovação (sobretudo a primeira reprovação) e a distorção idade-série mostraram impacto negativo de monta no rendimento, confirmando outras pesquisas (PARANÁ, 2001a, 2001 b). É preciso levar em conta também o relativamente reduzido número de matrículas da rede estadual nas séries iniciais.

Estado do Rio de Janeiro promoveu uma avaliação externa de grande porte, depois interrompida por descontinuidades administrativas. Os testes de rendimento discente mostraram que a maior parte dos alunos, pelo menos em torno de dois terços, atingiam os níveis mais altos de aprendizagem. Ou seja, os ciclos não levavam a uma redução da aprendizagem, embora não se comparasse a situação antes e depois da adoção dos mesmos (OLIVEIRA, Z. M. R., 1998).

Uma avaliação de porte nacional, a do SAEB-2001, avaliou o impacto das políticas de não repetência sobre o desempenho acadêmico dos alunos do ensino fundamental. Os resultados não acusaram vantagens nítidas nem dos ciclos, nem do regime seriado, sendo, inclusive, os dos primeiros inferiores em certas séries e regiões. Portanto, os ciclos, que deveriam ser uma forma de organização escolar alternativa e vantajosa em face do regime seriado, não comprovam superioridade, ao contrário das expectativas. Por outro lado, haver ou não haver promoção entre as séries não conduz a desvantagens significativas em termos de rendimento discente. Ao contrário, a defasagem idade-série tem impacto muito negativo sobre o aproveitamen- 
to, levando ao fracasso. Pode-se supor que os ciclos, talvez por implantação distorcida, não alcancem os resultados almejados, enquanto a reprovação não dá mostras de melhorar o aproveitamento (INSTITUTO NACIONAL DE ESTUDOS E PESQUISAS EDUCACIONAIS, 1997, 1998, 2002; FERRÃO; BELTRÃO; SANTOS, 2002).

\section{A Escola Plural}

A Escola Plural é uma reestruturação escolar profunda implantada a partir de 1995 na rede municipal de Belo Horizonte. Em 1994 foi apresentado aos educadores o primeiro caderno em que estavam contidas as diretrizes. Este caderno e seus sucessores, que passaram por revisões, fixaram os eixos norteadores da Escola, a nova lógica de organização dos tempos dos professores, dos alunos e dos processos cotidianos, os conteúdos e processos e a avaliação. A proposta, de ousada reestruturação e bem concatenada, envolvia desde o princípio a construção coletiva de um novo ordenamento, mais democrático e igualitário. Esse ordenamento deve atender à necessidade de pluralidade de funções socioculturais, de espaços e de tempos que a sociedade espera dos sistemas escolares. Para tanto, a escola necessita abrir-se para vivências culturais, avançando na recuperação de sua função de espaço público privilegiado de cultura e centrando-se não na transmissão/recepção de informações e saberes, mas na sua constituição como centros da formação coletiva. Com os currículos abertos para a produção cultural da cidade e para as dimensões que os transpassam, segundo o seu projeto, os profissionais criam mecanismos de intervenção na estrutura escolar, nos valores e na cultura que ela materializa. Mais ainda, enquanto a escola usualmente separa o tempo da formação e o da ação, que deixam de ter sentido em si, a Escola Plural se propõe a possibilitar a vivên- cia de cada idade de formação sem interrupções. Desse modo, a infância e a idade adulta são igualmente idade para formação e vivência de direitos plenos. Para isso, a escola passou a agrupar os seus alunos segundo a idade e a desenvolver a socialização adequada a cada idade-ciclo de formação. A sua "nova lógica dos tempos" levou à organização de três ciclos: 1) o da infância, para as idades de formação de seis-sete, sete-oito e oito/nove anos, com agrupamento das turmas de seissete, sete-oito e oito-nove anos; 2) o da préadolescência, para as idade de formação de nove, dez e 11-12 anos, com agrupamento das turmas de nove-dez, dez-onze e 11-12 anos; 3) o da adolescência, para as idades de formação de 12, 13 e 14-15 anos, com agrupamento das turmas de 12-13, 13-14 e 14 15 anos. A permanência de alunos no ciclo de idade por mais de um ano considera-se excepcional, o que exclui a retenção dos discentes. Em coerência com a nova lógica de tempos e com a associação entre cultura e, portanto, vivências do aluno, e currículo, os conteúdos disciplinares devem romper as barreiras e trabalhar com temas transversais e projetos de trabalho.

A avaliação, por sua vez, deixou de ter caráter seletivo ou classificatório, passando a incidir sobre aspectos globais do processo, visando a identificar os problemas e avanços e redimensionar a ação educativa. Daí a sua divisão em: 1) inicial, para organizar em turmas os alunos de um mesmo ciclo de formação, sem caráter de homogeneização, mas de organizar grupos que possam interagir, observando a idade, a experiência escolar anterior, o universo e as vivências culturais; 2) avaliação contínua, para constatar o que está sendo construído pelos alunos e o que está em vias de construção, de modo a identificar dificuldades e programar atividades diversifica- 
das; 3) avaliação final, que serve para ter um diagnóstico global do processo vivido, para organização do próximo ciclo de formação, em vez de definir aprovação/reprovação (BELO HORIZONTE, 2003; CONGRESSO POLÍTICO-PEDAGÓGICO DA REDE MUNICIPAL DE ENSINO/ESCOLA PLURAL, 2003).

Como se pode observar, a Escola Plural constitui um projeto de alteração dos códigos educacionais, no sentido da distinção hipotética de Bernstein (1977, 1990), isto é, princípios subjacentes que modelam o currículo, a pedagogia e a avaliação. $\bigcirc$ primeiro desses códigos é o tipo justaposto, com rigidez de fronteira entre os conteúdos e entre estes e o conhecimento cotidiano, além de escassa influência dos professores e alunos sobre a seleção, organização e pedagogia do conhecimento. $\bigcirc$ segundo é o tipo integrado, que apresenta características opostas. Mudanças desta ordem, obviamente, não se implantam sem dificuldades e impasses, o que é interessante para se levar em conta em experiências desta envergadura.

Embora visando a legitimar ousadas experiências prévias de algumas escolas, a proposta surpreendeu toda a rede municipal, ao ser implantada de uma só vez (DAL$B E N, 1998)$. A maioria dos professores não enxergou nessa proposta a continuidade com práticas anteriores e muitos profissionais se sentiram "desarmados", "pressionados" e "desarticulados". Parte substancial da resistência originou-se de ser uma proposta de escola para pobre e do temor pela perda de qualidade.

Dalben (1998), avaliando o período inicial de implantação, supunha que a Escola Plural contemplaria as expectativas dos pro- fissionais das escolas, dados os seus princípios e críticas à escola tradicional, mas isso não aconteceu. De qualquer modo, os profissionais da rede, em todos os níveis, passaram por um processo educativo inusitado que lhes exigiu clareza e senso crítico.

Das lições extraídas, Carneiro (2002) destaca que a Escola Plural esbarra em questões como a dificuldade de propor um projeto com características universalizantes em meio à heterogeneidade de posições e disposição de leitura e de práticas docentes; resistência do professorado; emergência de leituras não autorizadas pelo projeto por seu contrato narrativo; ambigüidade de sentimentos e posições antagônicas em relação aos órgãos de formação, como o CAPE, visto ora de modo positivo, ora criticado como mais um braço da Prefeitura. E alerta para a necessidade de evitar a ilusão de que o etnocentrismo das pedagogias tradicionais e seu desprezo pelas culturas não acadêmicas, bem como sua rejeição pela diversidade, possam ser facilmente "corrigidas, mediante a aplicação de pedagogias inovadoras". Corre-se então o risco de reservar pedagogias não tradicionais aos alunos das classes populares, com a educação ligada ao concreto, enquanto os alunos privilegiados seguem, na nossa expressão, o código justaposto, com suas fronteiras entre o conhecimento escolar e não escolar, tornando diferentes os possuidores do primeiro.

Esta série esperada de impasses e dificuldades é proporcional à profundidade das mudanças pretendidas, mas deve-se levar em conta que é uma experiência possibilitada, em parte, pelas características da rede municipal, sobretudo o nível de preparação e pioneirismo profissionais (SOUZA, 2000), fatores aos quais acrescentamos 0 
tamanho da rede, a agregação geográfica e os recursos fiscais nada desprezíveis, o que situa Belo Horizonte distante da maioria das redes escolares.

As pesquisas disponíveis apontam para algumas outras dificuldades de uma experiência considerada em implantação (FREITAS, 2000), que, pela sua complexidade, não são de surpreender:

- As manifestações de apoio ou oposição com base nas representações sociais da educação dos atores escolares, que ditam caminhos e processos tidos por esses grupos como válidos. Ligada a essas representações encontra-se a interpretação do fim da reprovação como promoção automática incondicional, o que, à luz da literatura aqui resenhada, não é exclusivo do caso da Escola Plural.

- As expectativas dos pais em face da educação, com sua função de preparar o filho para um futuro, o que quase sempre passa pela preparação para conseguir boas qualificações ou condições de competir por melhores condições de vida, inclusive concursos públicos e processos seletivos da educação superior (FREITAS, 2000). Junto com o sistema de avaliação e o fim da não retenção, não compreendido por professores, alunos e famílias, o limite da proposta era o temor das famílias de que o aluno chegasse ao fim do terceiro ciclo sem conhecimentos mínimos considerados adequados ao ensino fundamental, inclusive alfabetização (SOUZA, 2000).

- A concepção do ensino-aprendizagem pelos educadores como decorrente de um conjunto de atitudes e comportamentos de ordem psíquica dos educandos e menos como relação pedagógica entre educandos, educadores e conhecimento. No primeiro caso, a vontade, o esforço e o interesse do aluno são motores fundamentais, determinantes da aprovação/reprovação. No segundo caso, os resultados pedagógicos emergem da interação entre fatores intra e extra-escolares.

- A visão pragmática do trabalho docente, concebido como um fazer imediatista, que acaba por perpetuar a dicotomia teoria/prática e os leva a ver o tempo extra-classe como momentos para planejar, construir projetos, discutir problemas e não espaço da formação continuada dentro da escola.

- O descompasso entre a formação inicial do professorado e a identidade docente que se constrói no interior dos movimentos sociais e das escolas.

\section{A Progressão Continuada}

Em 1998 o Estado de São Paulo implantou a progressão continuada, estabelecendo dois ciclos de quatro séries no ensino fundamental, ao fim dos quais pode haver a retenção dos alunos. Adotada por uma imensa rede escolar, a alternativa, como veremos, implica mudanças menos profundas que a da Escola Plural, mas nem por isso livre de resistências. Certamente em face de dificuldades prévias antes mencionadas, foram tomados cuidados especiais, como a prévia reorganização da rede física, o aumento de horas para os alunos, a criação de coordenação pedagógica e horas de trabalho pedagógico em todas as escolas (ALAVARSE, 2002). A Deliberação $n^{\circ}$ 7/97 do Conselho Estadual de Educação foi, no mínimo, cautelosa. Levando em 
conta o direito de toda criança à aprendizagem, exigiu estrutura bem definida de avaliação contínua, recuperações paralelas contínuas e, no final do período letivo, avaliação da aprendizagem, do desenvolvimento do aluno, do próprio ensino e de caráter institucional. Com isso, perdiam sentido as expressões aprovação e reprovação, substituídas por progressão, aprendizagens diferenciais e desenvolvimento global. A avaliação deve ser entendida como mecanismo eficaz de ajustar o ato pedagógico à realidade dos alunos e não como meio artificial e automático de empurrar os alunos. Após a recuperação das férias, os alunos, segundo seu desempenho escolar, podem ser enquadrados em cinco categorias: promovidos, retidos, promovidos parcialmente, retidos parcialmente e evadidos.

Os promovidos são os que alcançam desempenho satisfatório e $75 \%$ ou mais de freqüência. A promoção parcial na oitava série do segundo ciclo e em todas as séries do ensino médio ocorre se o rendimento for insatisfatório em até três componentes curriculares e atendidas as condições legais de freqüência. A retenção parcial dos alunos da oitava série do segundo ciclo e de todas as séries do ensino médio se faz quando o rendimento é insatisfatório em mais de três componentes curriculares. Nesse caso, há retenção, com o aluno freqüentando as aulas dos componentes curriculares em que foi retido. A retenção acontece nas séries em que a freqüência for menor que $75 \%$ e o desempenho insatisfatório. Na quarta e oitava séries e ao final de cada série do ensino médio e outros cursos, também ocorre retenção se o rendimento for insatisfatório, mesmo com freqüência igual ou superior a $75 \%$. Os evadidos são os que têm freqüência menor que $75 \%$ e não participam das avaliações finais.
De certo modo, ao contrário da Escola Plural, a estrutura seriada e seus componentes curriculares não foram profundamente tocados, o que, numa rede estadual muito maior, poderia ser mais compreensível e palatável aos atores escolares. Para deixar claro que não se tratava de uma política de promoção automática, os resultados do SARESP, Sistema Estadual de Avaliação do Rendimento Discentes (de caráter universal e não amostral), passaram a decidir se os discentes podiam ser aprovados ou se deveriam ficar retidos ao fim de cada ciclo, isto é, foi utilizada a avaliação externa como coadjuvante, à semelhança dos casos, adiante referidos, da Suécia e do Reino Unido. Ao mesmo tempo, as avaliações institucionais externas passaram a hierarquizar os estabelecimentos segundo o rendimento, o que dava acesso a premiações, estabelecendo uma competição entre as escolas, aparentemente similar, pelo menos em parte, à experiência britânica. Um dos resultados foi a resistência e aparente desresponsabilização dos professores, por terem perdido a autonomia de julgamento dos alunos e por se envolverem numa teia de competição (FREITAS, 2002).

De qualquer modo, o Estado tem conseguido notórios avanços na correção do fluxo de efetivos discentes, ao mesmo tempo em que o rendimento médio detectado pelo SARESP se tem mantido. Assim, pelo menos em termos médios, a progressão continuada não se tem feito, aparentemente, às expensas do aproveitamento discente. Porém, o fato de os alunos multirrepetentes avançarem e saírem da rede escolar, não tem melhorado o aproveitamento médio, permite indagar se os alunos que permanecem não estariam tendo rendimento inferior, o que daria como resultado final a estabilidade das médias em níveis estatisticamente significativos. 
As pesquisas naturalísticas, entretanto, abrem uma janela para o mundo da sala de aula. Ainda que a seleção das escolas possa ser questionada e não se possa dizer se os acontecimentos analisados são singulares ou não, é relevante ter em conta que a proposta da progressão continuada, pelo menos nos casos estudados, está sendo reinterpretada de maneira viesada. Nem os professores em causa parecem ter entendido o seu espírito, nem as normas estatuídas pelo sistema de ensino parecem ajudar o funcionamento das escolas pesquisadas, que parece, sob certos aspectos, ter piorado. É o caso da reinterpretação da progressão continuada como promoção automática, que retira o esteio da escola tradicional, em termos de motivação extrínseca, sistema de sanções e estrutura de autoridade, além do apoio dos pais que, como seus filhos, com dificuldade parecem entender as novas políticas. Nas constatações de Guimarães (2001), ocorreu mera adesão formal à proposta, com manutenção da avaliação tradicional e de pressões para o aproveitamento dos alunos, porém com promoção automática ao final. Com isso veio um cortejo de problemas quanto ao interesse e à disciplina, iá que os comportamentos escolares passaram a ser guiados, na percepção dos atores, pela certeza de não haver qualquer tipo de retenção, alterando-se as bases da ordem social na escola e do chamado contrato social (CRAHAY, 1996) sobre que ela se baseia.

\section{Aceleração da Aprendizagem}

Enquanto os ciclos buscam evitar a retenção, a aceleração da aprendizagem é uma forma de desseriação que visa a recuperar o tempo perdido. Se bem que haja vários programas e formas de execução diferentes, eles tendem a elevar a auto-estima dos alunos e a oferecer condições especiais de ensino-aprendizagem para alunos com distorção idade-série. No caso do Acelera Brasil, há um conjunto de medidas simples e claras, mas integradas que, segundo as expectativas, se potencializam mutuamente (OLIVEIRA, J. B. A., 1998).

Vários desses programas têm tido avaliação externa constante (PLACCO, ANDRÉ; ALMEIDA, 1999). Análises quantitativas indicam avanços consideráveis dos alunos e elevadas economias, compensando o custo dos programas, superior ao custo médio aluno/ano da escolaridade regular. No entanto, menores investimentos, representados pela falta de alguma/s medida/s acima, conduzem a resultados mais modestos. Esta é, portanto, uma questão básica: se o tratamento é mais diluído, os resultados são inferiores. Fica claro da literatura que a questão não é meramente técnica, como, por exemplo, de haver ou não haver material de ensino-aprendizagem, mas envolve efetivo compromisso político, que se traduz, inclusive, na regularidade da chegada dos recursos. Não há, assim, segundo a literatura, nenhum segredo ou complexidade. Todavia, é preciso considerar que se trata de um programa inserido na escola, não de uma reestruturação completa das escolas e do ensino.

As avaliações externas constatam que, de modo geral, o aproveitamento dos alunos fica ao nível dos colegas das séries atingidas ou pouco abaixo, mostrando que se trata de promoção com atingimento dos objetivos e não de promoção "social". Ao contrário, a aceleração conduziu, nos casos estudados, ao avanço em termos da proficiência, tal como mensurada pelo 
SAEB. A auto-estima, elemento a que os programas dão grande relevância, situou os egressos reintegrados ao ensino regular em nível inferior ao dos seus colegas, se bem que as diferenças não fossem estatisticamente significativas. Com efeito, pesquisas naturalísticas caracterizaram os bons resultados e a aceitação do programa por alunos, pais e professores, portanto, sem se detectarem as dificuldades reveladas pela introdução direta ou indireta, via reinterpretação, da promoção automática. Não há evidências de que os programas tenham entrado nos conflitos revelados pelas mudanças revolucionárias das escolas, introduzidas ou pretendidas em numerosos casos. É bem verdade, entretanto, como citado acima, que se trata de programas, menos ameaçadores porque têm início e fim.

Um calcanhar de Aquiles detectado foi o reingresso no ensino regular, em que os alunos que passavam pelos programas voltavam a encontrar as dificuldades que os haviam conduzido à distorção idadesérie, o que leva à pergunta sobre a possibilidade de a aceleração da aprendizagem estar enxugando gelo, isto é, melhorando as condições de grupos de alunos, enquanto a escola continua a gerar novos contingentes de defasados (SAMPAIO, 2000).

\section{Aspectos Favoráveis aos Ciclos}

As pesquisas não se limitaram a constatar resultados, mas, com freqüência, a apontar aspectos que favoreciam e desfavoreciam a implantação e o sucesso dos ciclos. É surpreendente que os principais são quase óbvios e indispensáveis à efetivação de quaisquer inovações educacionais com certo nível de complexidade, como os ciclos. $\bigcirc$ que se depreende é que o magistério precisa compreender e aderir à inovação, ser valorizado, ter mais tempo para se dedicar aos alunos e ter certa experiência para enfrentar os desafios de uma proposta complexa. Outros esteios são os alunos e suas famílias, que precisam de acompanhamento, de compreender as inovações e apoiá-las. Os docentes precisam também de uma formação continuada eficaz, junto à escola e não em programas de massa, além de jornada ampliada. Aliás, os professores que tinham sucesso com alunos "difíceis", isto é, os mais aptos a lidar com a diversidade, eram mais favoráveis à inovação. $\bigcirc$ projeto pedagógico precisa envolver toda a comunidade escolar. Evidentemente, o diretor e a coordenação devem apoiar o projeto e haver clima favorável na escola à aprendizagem. Os alunos, por seu lado, precisam ter mais tempo letivo para melhorar a sua aprendizagem, desde que esse tempo não seja a repetição do que se faz no tempo usual. Além disso, os ciclos exigem medidas complexas de implantação, com ações coerentes, como deve ocorrer em todas as burocracias públicas e privadas, mesmo os sistemas escolares tendo desvios significativos em relação às concepções clássicas. Também requerem maiores investimentos financeiros, $\mathrm{O}$ que indica não serem formas de, aritmeticamente, baratear a educação. Eles levam a grandes economias, porém, ao proporem uma educação de melhor qualidade, sem os vícios da pedagogia da repetência, incorrem em custos, que, naturalmente, podem ser compensados pelos cortes do desperdício. $\bigcirc$ desenvolvimento de novos valores éticos e políticos é também necessário, visto que as inovações introduzidas representam verdadeira revolução na escola.

Em outras palavras, agir certo segundo o senso comum e as evidências correntes de 
pesquisa no panorama internacional é o que facilita a adoção e a implantação dos ciclos. Clima da escola, papel do diretor, adesão consciente dos professores, protagonismo dos professores, aumento da jornada escolar e outros aspectos são bastante conhecidos da literatura (SCHEERENS; BOSKER, 1997; SCHEERENS, 2000). Respeitar que as redes escolares são grandes burocracias e precisam estabelecer elos coerentes e firmes em sua ação, com fluxos de baixo para cima e de cima para baixo, é também outro fator. As pesquisas aparentemente apuraram com rigor esses aspectos favoráveis. É possível, porém, que a caixa preta da sala de aula e da escola, se investigada mais profundamente, pudesse revelar o que professores fazem ou deixam de fazer e que conta para o sucesso da desseriação. É possível que, diante de fatores tão nitidamente influentes e visíveis, alguns pesquisadores tenham considerado a sua busca encerrada. Como pesquisas geram novas indagações e pesquisas, passado o ofuscamento dos aspectos mais influentes, é provável que, descendo ao nível micro, se desdobrem outros aspectos de modesto perfil, mas de decisiva importância.

Uma lição que parece óbvia, mas nem sempre levada em conta na prática, é a participação dos professores. As melhores concepções pedagógicas e as melhores medidas da gestão se frustram se os professores não são persuadidos e preparados para levar a efeito determinadas inovações. Sem dúvida, os sistemas escolares são burocracias públicas, mas não típicas burocracias, em que o taylorismo-fayolismo possa florescer com facilidade (aliás, já não floresce sequer nas empresas produtivas). Sejam consideradas como instituições flexivelmente articuladas ou de outra forma, seu modo de atuação e sua estrutura não encontram no professor um executor automático de tarefas fáceis, porém um sujeito (social) que depende do convencimento, da participação e da preparação para tarefas complexas (VASCONCELLOS, 1999). Igualmente são importantes dois atores: os alunos e suas famílias. Os primeiros convivem na escola num ambiente em que se mesclam consenso e conflito. Mudanças de normas e alterações no regime de incentivos e sanções são fundamentais para a sua conduta. Quanto aos pais, junto com os alunos, sobretudo a partir de certa idade, têm aspirações sociais importantes em face da escolaridade e decidem sair ou permanecer nela, arcando com os seus custos, inclusive de oportunidade (isto é, de cursar a escola em vez de fazer outra coisa). Não adianta tratar o professor como objeto tanto na escola tradicional quanto na "renovada".

\section{Aspectos Desfavoráveis aos Ciclos}

São precisamente essas lições negligenciadas que emergem dos aspectos desfavoráveis identificados pelas pesquisas, alguns com grande reiteração. Em primeiro lugar, há que se observar a gestão educacional, que foi, nas últimas décadas, e tem sido objeto de preocupações e de realizações. $\bigcirc$ panorama descerrado é de incipiência das alterações, vez que os sistemas escolares demonstraram não respeitar características fundamentais de qualquer inovação em grandes burocracias públicas. Assim, a fragilidade dos processos de implantação implicava uma série de acidentes no trajeto do centro até às salas de aula, com elos desentrosados, sem manter a coerência indispensável para que algo seja efetivo nos sistemas escolares. Com uma 
ação dispersiva e desentrosada, carente de orientação nas diversas etapas, acabava-se por perder o ímpeto renovador e levar a acontecer um espectro daquilo que havia sido previsto. No período de redemocratização tinhase claramente em vista que inovações não poderiam fluir no velho esquema de centro planejador - periferia executora. Tanto assim que os projetos, especialmente de São Paulo e Minas Gerais, foram amplamente discutidos com o magistério e numerosas - como inéditas - foram as oportunidades de discutir e até de votar proposições. Apesar disso, houve contradições no processo e uma adesão parcial e superficial de parte ponderável do professorado, que não estava convencido de que as propostas superavam a sua malfadada, mas bem conhecida "pedagogia da repetência". Foi assim que, em particular no Estado de São Paulo, chamados a participar nos anos 80, os professores ofereceram respostas frustrantes para a cúpula renovadora da Secretaria, que não poderia aceitar a continuação do status quo. Em conseqüência, o magistério não reconheceu as suas opiniões quando a proposta dos ciclos chegou às escolas. Por outro lado, os anos 80 foram marcados por longas e freqüentes greves dos professores, que buscavam recompor a sua remuneração, inclusive ante o acelerado processo inflacionário. Em tal clima, eram difíceis o entendimento e a colaboração. No âmbito das mútuas relações de desconfiança, entre escolas e administrações regionais e central, existiam mecanismos de acomodação em que as primeiras se caracterizavam por preservar, parte das rotinas, até salutarmente, enquanto as últimas mudavam freqüentemente ao sabor das injunções políticas. Com isso, unidades escolares se adaptavam epidermicamente aos novos discursos. No caso dos ciclos o porte da inovação era demasiado grande para manter as aparênci- as de mudança, mas, ainda assim, a resseriação foi constatada sob diversos ângulos. Desse modo, embora houvesse a continuidade dos ciclos, sob vários ângulos, dependendo da administração, de um lado, criouse uma contradição entre a roupagem democrática da discussão e a resistência do professorado, enquanto, por outro lado, contrastavam o ímpeto renovador e a descontinuidade da gestão central com a ausência ou escassez de um esforço contínuo e persistente da formação continuada do professor, que, segundo uma avaliação, frutificava após anos de pacientes esforços (ALVES, 2002). Por outro lado, as modificações estruturais da escola, inclusive com a reorganização do espaço e tempo, eram de tal porte que não encontravam correspondência no apoio e no trabalho de adesão dos atores envolvidos.

A gestão escolar, por seu lado, se ressentia da falta de um vivo projeto pedagógico, que reunisse as forças da comunidade educativa. A penúria de meios era também significativa. $\bigcirc$ remanejamento indiscriminado de turmas, numa sociedade desigual, acabou, pelo menos em certos casos, por estratificar os alunos por status socioeconômico, ocasionando oportunidades desiguais que amplificam as disparidades sociais. No âmbito da escola, portanto, pouco as pesquisas constataram no sentido de persuadir e cativar os atores principais, entre eles professores, alunos e suas famílias. Nada mais desaconselhável quando se trata de efetuar uma verdadeira revolução nas finalidades, objetivos, métodos e avaliação da escola.

Do lado do magistério, os problemas típicos da crise fiscal dificultaram a adoção de uma inovação que toca o nervo da vida 
e da identidade profissional do professor. Como não se pode fazer a omeleta sem quebrar os ovos, não se poderia combater a pedagogia da repetência por meio de meros retoques. Com isso, o professor passou por várias tensões e exerceu a resistência no seio de burocracias que contam com arenas conflituosas, em vez de constituir harmônicos relógios.

Uma das mais difíceis vem a ser a alteração do sistema de controles na sala de aula, sem o poder da sanção maior da reprovação, sanção essa que tem a ver com capacidades cognitivas, mas também com comportamentos e atitudes dos alunos, sujeitos a julgamentos e avaliações por caminhos não raro preconceituosos. Já que a escola é concebida por alguns autores como um grupo em conflito potencial ou real, em que a freqüência dos alunos e professores e as prescrições curriculares são obrigatórias, à semelhança de uma panela de pressão, o papel das sanções (e não só dos incentivos) é axial (GOMES, 2005). Assim, não é difícil compreender esse motivo da oposição dos professores aos ciclos, eles que se encontram na ponta do sistema, enfrentando suas dificuldades, em parte, sozinhos.'

Quanto mais a escolaridade se desenrola num clima de conflito latente ou aberto mais depende de um sistema de sanções para manter a ordem social. Quanto maior o consenso em que se baseia, ainda que se estabeleçam conflitos, cabem mais os incentivos que as sanções, embora seja difícil manter um grupo social deste tipo sem as últimas. Ora, com a pedagogia da repetência, a coesão da escola depende mais dos conflitos e das sanções que do con- senso e dos incentivos. Como resultado, estabelecida a promoção automática ou de alguma forma facilitada, essa ordem fica privada de um dos seus maiores ou do seu maior pilar, tendo em vista o corte tradicional da escola. Em conseqüência, os professores tendem a se opor à mesma e, instados por decreto a mudar uma prática, conseguem não raro cumprir formalmente a legislação sem modificar a avaliação e suas representações, empurrando a reprovação para o fim do ciclo básico ou, ainda, abandonam o aluno com baixo aproveitamento, desresponsabilizando-se por ele. Isso ocorreu, segundo Sousa (1999) porque a proposta não considerou o valor de referência histórica dessas representações e a relação com o seu papel. Paro (2000, 2001), por sua vez, em pesquisa naturalística, observou a importância de uma tradição punitiva da avaliação na história de vida escolar de professores e da população em geral; o baixo autoconceito do professor, que se compensa com a inculpação do aluno, e a falta de concepção progressista de educação que suponha uma didática em que o educando seja autor e construtor da sua aprendizagem. $\bigcirc$ professor não tem o foco na aprendizagem do aluno, nem considera os seus resultados como elemento para rever o ensino. Ao contrário, é mais dramático passar sem aprender do que não ter aprendido.

Ainda no campo do magistério, a situação dos que o compõem leva a refletir cuidadosamente sobre as possibilidades de mudanças radicais e as suas implicações em termos de esforços. Considerando o Ceará, Estado relativamente desprivilegiado onde também foi adotado o sistema de

'Cf. os resultados de FREITAS, 2000; GUIMARÃES, 2001; FREHESE, 2001 ; PARO, 2001 ; SILVA; MELLO, 2001; RODRIGUEZ, 2002. 
ciclos, as pesquisas descrevem particularmente as difíceis condições das professoras alfabetizadoras. Uma pesquisa com histórias de vida revelou uma identidade fragmentada não fundada na crítica e na reflexão e um discurso baseado no amor e doação pelo magistério. Sem acesso a bens culturais fundamentais na ampliação dos seus conhecimentos, está ausente de discussões e decisões sobre a sua prática. Com uma formação precária e inadequada, não encontram esteio na competência, achando que qualquer uma pode ser professora, principalmente alfabetizadora (LIMA, 1995). Outra pesquisa qualitativa revelou que pelo menos parte delas, com a sua modesta formação, entendia que, com a promoção automática, não precisavam mais ensinar. A formação continuada, que poderia oferecer condições de superação, realmente tinha aspectos positivos, mas se apresentava como extremamente rala e frágil, consistindo de cursos pouco freqüentes (uma semana uma ou duas vezes ao ano, quando eram oferecidos), com falta de periodicidade, às vezes interrompidos, e caracterizados geralmente pela dissociação das demandas docentes, com grande peso à teoria (MAMEDE, 2000). Este mosaico das condições docentes do meio urbano e rural na Região Nordeste indica o quanto há por fazer e o quanto o que é feito deixa a desejar, apontando, mais uma vez, para a precariedade da implantação.

A dificuldade, portanto, reside no fato de que as mudanças da escola permanecem à tona, coexistindo processos incongruentes. Conforme as pesquisas resenhadas, o tratamento dispensado pelos sistemas aos professores, muitos deles praticantes e adeptos da pedagogia da repetência, não chegou a ser equacionado do modo mais feliz, com a formação continuada requerida. Ao contrário, parece que se convocaram os soldados para uma guerra sem que eles estivessem preparados e convencidos da legitimidade desta. Pior ainda, tocou-se fundo no papel e na visão desses atores sem prever como atuar em face das conseqüências, o que se assemelha à conduta do aprendiz de feiticeiro.

Com isso, à semelhança de outras inovações educacionais, as novas práticas com freqüência foram reinterpretadas com a manutenção das antigas, mantendo o corpo velho sob vestes novas. É o que dizem as constatações sobre currículo e avaliação. Mais ainda, sistemas, cheios de boas intenções, tenderam a fazer opções metodológicas gerais para a alfabetização. Com isso, muitos professores passaram a ter a angústia de abandonar os anatematizados modelos antigos sem dominar o novo, quando é discutível, observada a autonomia da escola, que se estabeleçam opções uniformes para todas.

No caso dos ciclos, a parte mais visível foi a promoção automática, precisamente o maior pomo de discórdia, abrindo possibilidades de ou se reduzirem os ciclos à ponta do iceberg ou manter as práticas tradicionais sob as referidas vestes novas, numa evidência de que Almeida Júnior (2002) não foi ouvido nem nos anos 50, nem depois deles. Fica claro das evidências de pesquisa ${ }^{2}$ que a reprovação não leva a aprender mais, antes pelo contrário aumenta a probabilidade de nova reprovação, enquanto mais de uma reprovação tende a elevar a probabilidade de repetência. De outro lado, autores como Pedro Demo (1998) alertam para a tentação de

${ }^{2}$ Cf., também, BARROS; MENDONÇA, 1998; ESPÓSITO; DAVIS; NUNES, 2000. 
promover sem a devida aprendizagem, sob o argumento de não causar danos à autoestima do aluno, quando é preferível a pedagogia da verdade. A promoção sem aprendizagem correspondente constitui um ônus sobretudo para a escola pública e para os alunos socialmente menos privilegiados, pois desmoraliza a escola pública e torna-a coisa pobre para o pobre.

Assim, se faltam evidências que justifiquem e legitimem a reprovação - e reprovação em massa - que ainda é praticada no Brasil, a leniência (que nada tem a ver com os ciclos, mas estes correm o risco de ser a ela reduzidos) não é melhor remédio. Ao contrário, corre-se o risco de esconder sob o manto da regularização de fluxo uma aprendizagem medíocre, como têm evidenciado os resultados modestos do SAEB e do PISA. As exigências podem ser niveladas por baixo, como por meio de um rolo compressor, deixandose de lado a necessidade de exigências crescentes de aprendizagem. Com isso, embora não querendo, pode-se gerar o pior dos mundos: regulariza-se o fluxo de alunos e se reduzem os custos, satisfazendo a gestores e às eternas limitações orçamentárias da educação; pais e alunos incautos ficam satisfeitos porque, não havendo reprovação, há ilusão de aprendizagem; o trabalho do professor é, de certa forma, facilitado, na medida em que se exige pouco dos alunos e, por extensão, do corpo docente e o sistema educacional, enquanto olha para o seu umbigo, fica satisfeito com a adequação do País aos indicadores estatísticos internacionais.

\section{Que Fazem Outros Países?}

As experiências nacionais mostram dificuldades relativas à mudança do pacto so- cial da escola, agravadas muitas vezes por sérios problemas de implantação. Raramente - Brasil optou pela promoção automática, embora as políticas de desseriação tenham sido confundidas com a mesma, que pode estar sendo praticada na realidade. Há países, entretanto, que adotam a promoção automática e alcançam elevados níveis médios de aproveitamento, embora ela possa servir como biombo que esconde desigualdades e procedimentos regressivos. Vale dar uma olhada no que eles fazem, levando em conta que, ao contrário do Brasil, está consolidado o contrato social que fundamenta o funcionamento das escolas.

O Japão é um caso específico que indica a relação entre a cultura e seus valores e a escolarização. Conhecido pelo longo tempo letivo e excelentes resultados nos testes internacionais, o país desafia supostas "verdades estabelecidas", como a relação entre promoção automática e elevado número de alunos por turma e baixo aproveitamento (GOMES, 1993). O único requisito para o ingresso na escola é haver completado seis anos de idade, do mesmo modo que é a idade e não o desempenho que determina a passagem de uma série anual à outra. A escola não existe para incentivar um processo competitivo entre as crianças pequenas, mas um meio para reforçar a unidade cultural, a solidariedade e a homogeneidade, a construção do espírito de corpo em detrimento das diferenças individuais. Por esse motivo não fazem sentido nem a reprovação, nem a aceleração da aprendizagem para os superdotados. Ao mesmo tempo, a escolarização é universal e a evasão quase zero (VELLOSO DE SANTISTEBAN, 1994). No entanto, a competição é acerba na passagem entre os níveis de ensino, a partir do fim do primário, bem como no acesso às 
escolas particulares, com exigências familiares e sociais de bom desempenho e sucesso nos exames, a partir da escola secundária. Ainda assim, a competição se faz predominantemente entre alunos egressos de várias escolas do que entre discentes de uma mesma escola (NAGATA, 2002).

Desse modo, a promoção automática não significa um relaxamento da aprendizagem, mas a conseqüência do cultivo de determinados valores pela educação comum e obrigatória em nível primário. Ratificando o valor dessa educação geral para todas as crianças, as condições das escolas são em grande parte as mesmas em todo o país. $\bigcirc$ clima escolar é de exigências crescentes, com alto profissionalismo dos docentes, avaliação contínua dos alunos, atenção constante às dificuldades de aprendizagem e engajamento familiar. Há, portanto, um incentivo da cultura, no sentido de valorizar a educação. Esse amparo envolvente existe, de maneiras similares, nos chamados Tigres Asiáticos. Ou seja, a escola e a figura do professor têm profundo significado. Simplesmente não se pensaria em deixar de estudar porque se passa de ano automaticamente.

A Suécia também conjuga a promoção automática na escolaridade compulsória com freqüentes resultados muito favoráveis nas avaliações internacionais. A educação obrigatória inclui o ensino básico primário e secundário, dos sete aos 16 anos de idade, não havendo reprovações. $\bigcirc$ processo de avaliação é contínuo, tendo sido abandonados os números, substituídos por quatro menções no ensino secundário. As notas individuais que se adquirem ao longo do curso vão sendo deixadas de lado e globalizam toda a avaliação da aprendizagem com relação aos objetivos de todo o curso (WITTEK, 1997). Os pro- fessores dão notas aos alunos de modo inteiramente livre, porém a avaliação nacional exerce um efeito indicativo, com efeitos morais significativos, já que os alunos têm o seu desempenho comparado com o dos colegas de todo o país. Dessa forma, no quarto e sétimo anos os alunos têm testes diagnósticos de língua materna e matemática. No oitavo ano são submetidos a um teste padronizado de inglês e no nono ano são administrados testes também padronizados de língua materna e matemática. Estes não reprovam, mas têm valor indicativo para os professores (assim como alunos e pais) saberem como estão os seus discentes em relação aos de outras escolas em aprendizagens fundamentais. Obviamente, disparidades significativas tendem a causar mal-estar e medidas corretivas, já que a qualidade da educação é valor altamente prezado pela sociedade, que responsabiliza as escolas. Além disso, a Suécia instaurou uma avaliação nacional a partir de 1989, que focaliza os saberes e o saber fazer relativos ao currículo e à metodologia de trabalho dos alunos da escolaridade obrigatória. A avaliação é formativa e se destina a ajudar os professores, visando a responder a duas questões: As escolas trabalham como deveriam? Os objetivos propostos às escolas são alcançados? Todos os professores recebem os resultados dos seus alunos, bem como os resultados nacionais. Todos os anos, ademais da avaliação quantitativa, procede-se à avaliação qualitativa das escolas. $\bigcirc$ conjunto das avaliações realizadas se traduz num relatório trienal ao governo sobre o estado da educação. $\bigcirc$ governo conta com o prazo de um ano para comunicar as medidas que tomará em função do relatório (LANDSHEERE, 1997).

Três aspectos podem ser destacados. $\bigcirc$ primeiro é a preocupação com a educação e os princípios da igualdade, construída ao lon- 
go de muitos anos de social democracia. $\bigcirc$ segundo é o abandono dos adereços da avaliação em favor de uma simplificação maior, numa atitude realista em face da precisão e validade do sistema. Em último lugar, a avaliação não é um ato solitário do professor, mas tem referências constantes aos níveis nacionais de aproveitamento, a que o aluno é constantemente comparado pela escola, assim como pelo próprio discente e sua família. Dessa forma, a promoção automática é inserida e responsabilizada num contexto público de resultados. No ensino médio, não obrigatório, essa responsabilização aumenta, com os alunos submetidos a testes nacionais. Cada docente deve justificar ante o conselho de professores as notas atribuídas a cada aluno em função dos resultados desses testes. Evidentemente, a qualidade só se sustenta se a educação constituir um forte valor para a sociedade, conjugando, assim, liberdade e responsabilidade.

Reino Unido, por sua vez realizou importantes reformas sobretudo nos anos 80 , tendo em vista elevar a competitividade internacional do país e, assim, introduzindo princípios de mercado na educação pública e particular. Em 1988 houve uma centralização significativa com a adoção de um currículo nacional, que inclui os objetivos, os programas, e os critérios de avaliação considerados apropriados para quatro etapas na educação da criança: cinco a sete anos, sete a 11,11 a 14 e 14 a 16, ao final das quais se levam a cabo exames oficiais. Ao fim do ensino primário, aos 11 anos de idade, o aluno deixa a escola com uma avaliação da sua "idade de leitura, compreensão, escrita e expressão", sendo admitida uma variação de menos dois a mais dois anos (nove a 13 anos).

A avaliação externa é um processo para induzir o sistema a caminhar em determinada direção, envolvendo não só a avaliação periódica do trabalho do professor, como também a avaliação do rendimento discente, por meio de amostra das populações de sete, 11, 14 e 16 anos, que deve determinar em que medida os níveis de rendimento atingem os alvos de aprendizagem, isto é, conhecimentos, competências e compreensão real que os alunos devem atingir ao fim de cada ciclo. A avaliação da aprendizagem resulta da combinação do julgamento dos professores com os resultados obtidos em testes elaborados fora da escola. Esses testes não são iguais para todas as turmas e os docentes podem elaborar provas a partir de um banco de questões.

Apesar do rigor das avaliações, a promoção é automática no ensino obrigatório e a organização dos alunos por unidade escolar é realizada por idade, cada qual correspondendo a uma série, isto é, adota-se a promoção automática, mas continua a seriação anual como referência para os objetivos de cada etapa curricular. A avaliação é contínua, não se expressando numa avaliação final de aprovação ou reprovação do aluno. Os grupos ou turmas são homogêneos quanto à idade, mas podem ser heterogêneos quanto ao grau de desenvolvimento e desempenho educacional dos alunos e dos seus diferentes graus de domínio dos componentes curriculares. Como a progressão escolar se faz pela idade, as escolas organizam subgrupos de discentes na mesma classe, de acordo com o seu nível de desenvolvimento e aprendizagem, ou formam turmas por diferentes níveis de aproveitamento. Dentre os processos para acertar o passo dos alunos em cada grupo, pratica-se a assistência individualizada ou tutoria, a ajuda de colegas mais adiantados aos mais atrasados e horas e trabalhos extras de recuperação (MELLO, 1993; EGIDO GÁLVEZ, 1997; LANDSHEERE, 1997). 
Como se pode observar, combina-se a promoção automática com a flexibilidade da organização, vigiada intensamente pela avaliação externa. Como então uma sociedade multiétnica lida com o insucesso escolar? Deve-se destacar, em primeiro lugar, a riqueza de recursos para a recuperação da aprendizagem, porém, num sistema competitivo, a divisão de turmas por aproveitamento é a prática do discutido tracking, também adotado nos Estados Unidos, assim como a divisão da turma em grupos de aproveitamento diverso e o cardápio curricular, para permitir escolhas mais ou menos fáceis a alunos com variadas disposições e disponibilidades. Como se sabe, a literatura discute interminavelmente a questão sobre os efeitos de tais formas de organização sobre a democratização educacional (GOMES, 2005). Pesquisas naturalísticas, entretanto, mais que outras tendem a apontar para a formação de um "sistema de quase castas", pelo qual o aluno, uma vez alocado a um grupo intraclasse ou turma, dificilmente circula, sendo muito reduzida a mobilidade ascendente. Além disso, a alocação é permeável a múltiplos vieses pessoais, étnicos e sociais do professor (RIST, 1970). Com isso, apesar de o sistema educacional ter avaliação externa e promover a competição entre as escolas, existe a possibilidade de diferenciação relativamente ampla de oportunidades educacionais. Um aluno socialmente desfavorecido pode ser matriculado numa turma "fraca" no início da sua escolaridade e assim prosseguir até o fim, sempre aprovado em turmas pouco aquinhoadas, ao passo que o contrário pode acontecer a um aluno socialmente privilegiado (CANEN, 1995). De qualquer forma, uma lição que se pode extrair é que a promoção automática nunca está sozinha na prática, mas associada a um conjunto de medidas que a tornam cara e não um meio de barateamento dos custos educacionais diretos.

\section{Conclusões}

A resenha da literatura nos mostra um conjunto vigoroso de reações à cultura da repetência e à perversa retenção de alunos que fazia o Brasil ter não uma pirâmide, mas um obelisco educacional. Como conquista concreta, o perfil hoje é de efetivos discentes que têm distorção idade-série cada vez menor. $\bigcirc$ País confirma de modo geral, portanto, o que diz a literatura internacional: reprovação não é remédio e não raro age como veneno.

Por outro lado, a experiência indica que países que adotam com êxito a promoção automática estão mergulhados numa cultura que valoriza a escola, onde o aluno é estimulado pela família e pela comunidade, tornando pouco aceitável a idéia de que seria desnecessário esforçar-se no estudo. Ao contrário, o aluno é cercado de todos os lados não só de incentivos e exigências, mas de um aparato de assistência e apoio para acertar o passo com os colegas e recuperar a sua aprendizagem. Em outras palavras, a promoção automática não barateia a educação, mas exige alto investimento de competência técnica e recursos financeiros. Não se pensaria nesses países em criar qualquer modalidade de promoção automática só para reduzir os custos e não fazer os dispêndios à altura das novas exigências.

Aqui está uma chave da questão: o Brasil mantém estável o seu baixo aproveitamento discente e corre o risco de contentarse com isso, inclusive porque a correção de fluxo proporciona substanciais economias. Se a reprovação diminui, deixa de haver duas, três ou mais vagas por aluno, o que não é nada desprezível. No entanto, o aumento da eficiência aliado à manutenção 
de modestos resultados deixa à mostra que a melhoria do fluxo escolar é necessária, mas não suficiente para elevar o intolerável nível de qualidade (KLEIN, 2003).

Não parece haver elementos para defender a reprovação, embora, como vimos, a retenção possa ser advogada no caso de conhecimentos básicos de que outros dependem fundamentalmente, como a alfabetização. Este foi um dos temores expressos por pais e professores: o avanço formal dos alunos sem que sequer se tenham alfabetizado. Ainda assim, pode-se aceitar que, apesar da desseriação, o rendimento discente brasileiro não despencou de 1997 em diante, nos termos do SAEB (INSTITUTO NACIONAL DE ESTUDOS E PESQUISAS EDUCACIONAIS, 1997, 1998, 2002), o que é uma visão parcial do processo educativo, mas a que se pode recorrer para grandes números. As médias, apesar dos amplos desvios padrões, têm mantido certa estabilidade em níveis considerados estatisticamente significativos pelos analistas. No entanto, como é notório, a qualidade expressa por esse desempenho é muito modesta. As competências correspondentes às médias dos nossos alunos são escassas e parecem ainda piores quando se verificam as variações em torno delas. Tanto isso é verdade que temos ficado na cauda das avaliações internacionais, como o PISA, e pouco acima da média latino-americana nas pesquisas do Laboratório de Qualidade da OREALCUNESCO (CASASSUS et al., 1998). Como a distorção idade-série tem diminuído, seria de esperar que, com o avanço ou a saída do sistema dos alunos multirrepetentes, o rendimento médio se elevasse. Isso, entretanto, não tem ocorrido, o que nos leva a indagar por que o rendimento dos alunos mais ajustados quanto à idade-série não contribui para níveis mais altos de proficiência. Estaria ele se deteriorando? Igualmente, sendo a organização desseriada supostamente superior à tradicional, seria também de esperar que concorresse para elevar o desempenho discente. Essa relativa estabilidade, entretanto, parece explicar-se porque a melhoria do fluxo escolar é necessária, mas não suficiente para elevar a qualidade (KLEIN, 2003). Uma possível pista explicativa é oferecida pelas pesquisas naturalísticas. No labirinto de resistências e demais dificuldades de implantação, as novas políticas podem ser reinterpretadas e praticadas, pelo menos em certas escolas, como promoção automática. Uma promoção automática pobre, que não tece em torno do aluno uma rede de proteção e exigência. Docentes e discentes se tornam trapezistas sem rede, em escolas precárias, onde os professores se encontram contrariados com a perda de status e identidade. $\bigcirc$ velho contrato social pode estar sendo rasgado sem que o novo seja nítido.

Em outras palavras, o País tem contemplado a correção de fluxo e tem alcançado êxitos. Isso, porém, não lhe basta mais, até porque é reconhecido que não adianta buscar resultados quantitativos primeiro e qualidade depois. É urgente, depois de duas décadas, dar passos decisivos em favor da qualidade, que já deveriam ter sido dados, inclusive por meio de políticas próprias, complexas e caras. $\bigcirc$ País não pode continuar patinando no baixo rendimento e ameaçando as indispensáveis cidadania e competitividade. Ou seja, é preciso avançar muito mais.

\section{Recebido em: 10/03/2005 \\ Aceito para publicação em: 03/05/2005}




\section{ABSTRACT \\ Alternative policies to school organization by grades: a way to the success?}

This paper presents a review of the research literature on primary education policies in the last 15 years in Brazil aimed to reduce the repetition rate by means of the adoption of cycles and other alternatives to the traditional organization in grades. The basic goal is to find if these policies have contributed to improve or to reduce pupils' performance. The study selected 62 research projects, with diverse theoretical and methodological approaches. Results show that different experiences have risks and disadvantages, among them the rupture of the so called social contract for school, partially based on the repetition threat. Accelerated learning projects have showed positive results. However, the deeper the changes aimed toward the educational codes, the stronger are the resistances. Policies not seldom neglect careful implementation. Research projects involving larger populations find that new policies do not improve or reduce pupils' achievement significantly. The international literature emphasizes the importance of strong support to pupils with difficulties. Comparative studies also show that repetition is a cultural, often biased phenomenon. Conclusions warn that policies implemented in the country Brazil may reduce their focus to the mere increase of efficiency and reduction of costs, by correcting the distortion age-grade. Nevertheless, low levels of quality and equity may remain. Keywords: Primary education. Repetition. Cycles. Accelerated learning. Continuous promotion. Educational democratization. Comparative education.

\section{RESUMEN}

\section{Políticas alternativas a la organización escolar en grados: ¿̇un camino para el succeso?}

Este trabajo es una reseña de las investigaciones sobre las experiencias de políticas educativas que, en los últimos 15 años en Brasil, intentan reducir las altas tasas de repitencia por medio de alternativas a la tradicional organización de la educación primária en grados. Fueron seleccionadas 62 investigaciones nacionales, con diversas orientaciones teóricas y metodológicas. Los resultados revelan que diferentes experiencias presentan riscos y limitaciones, entre ellas el rompimiento del llamado contracto social en que se basa la escuela y que tiene como una de sus bases la amenaza de reprobar el alumno. La acceleración del aprendizaje, como proyecto temporal, alcanza buenos resultados. Las políticas educativas muchas veces no son adecuadamente implementadas, sufriendo mayores resistencias cuando buscan cambiar más profundamente los códigos educativos. Sin embargo, los proyectos de investigación regionales o nacionales no presentan evidencias de reducción o de incremento del rendimiento discente por las políticas alternativas adoptadas. La literatura internacional destaca que los alumnos reciben cuidados muy especiales en los países que siguen la promoción automática, pero la reprobación es una expresión cultural. Las conclusiones advirten que las políticas educativas implementadas pueden incrementar la eficiencia y reducir los costes, mientras se mantienen los bajos niveles de calidad y equidad. Palabras-clave: Educación primária. Reprobación. Ciclos. Acceleración del aprendizaje. Promoción continuada. Democratización de la educación. Educación comparada. 


\section{Referências Bibliográficas}

ALAVARSE, O. M. Ciclos: a escola em (como) questão. 2002. Dissertação (Mestrado em Educação) - Universidade de São Paulo, São Paulo, 2002.

ALMEIDA JÚNIOR, A. F. Repetência ou promoção automática. In: CONSELHO ESTADUAL DE EDUCAÇÃO (SP). A voz dos educadores: textos escolhidos. São Paulo, CEE, 2002. p. 72-81.

ALVES, M. L. A formação continuada no ciclo básico: memórias. In: ENCONTRO NACIONAL DE DIDÁTICA E PRÁTICA DE ENSINO, 11., 2002, Goiânia. Anais ... Manaus: Sonopress - Rimo da Amazônia, 2002. 1 CD-ROM.

AMADIO, M. Primary school repetition: a global perspective. Genebra: UNESCO/IBE: UNICEF, 1996.

BARROS, R. P.; MENDONÇA, R. Conseqüências da repetência sobre o desempenho educacional. Brasília, DF: IPEA, 1998.

BELO HORIZONTE (MG). Secretaria Municipal de Educação. Referenciais curriculares: educação básica: escola plural. Belo Horizonte: Secretaria Municipal de Educação, 2003.

BERNSTEIN, B. Class, codes and control. Londres: Routledge Kegan Paul, 1977. v. 3.

. Class, codes and control. Londres: Routledge, Kegan Paul, 1990. v. 4.

BRASIL. Lei $n^{\circ}$. 9.394, de 20 de dezembro de 1996. Estabelece as diretrizes e bases da educação nacional. Diário Oficial [da] República Federativa do Brasil, Brasília, DF, 23 dez. 1996.

CANEN, A. Teacher education in an intercultural perspective: a parallel between Brazil and UK. Compare, London, v. 25, n. 3, p. 227-237, 1995.

CARNEIRO, G. C. O oficial-alternativo: interfaces entre o discurso das protagonistas das mudanças e o discurso da escola plural. 2002. Dissertação (Mestrado em Educação) Universidade Federal de Minas Gerais, Belo Horizonte, 2002.

CASASSUS, J. et al. Primer estudio internacional comparativo sobre lenguaje, matemática y factores asociados en tercero y cuarto grado. Santiago, Chile: UNESCO-OREALC, 1998. 
CONGRESSO POLÍTICO-PEDAGÓGICO DA REDE MUNICIPAL DE ENSINO/ESCOLA PLURAL, 2., 2003, Belo Horizonte. Anais ... Belo Horizonte, MG: Secretaria Municipal de Educação, 2003.

CRAHAY, M. Podemos lutar contra o insucesso escolar? Lisboa: Instituto Piaget, 1996.

DALBEN, A. I. L. F. A avaliação escolar: um processo de reflexão da prática docente e da formação do professor no trabalho. 1998. Tese (Doutorado em Educação)-Universidade Federal de Minas Gerais, Belo Horizonte, 1998.

DEMO, P. Promoção automática e capitulação da escola. Ensaio: avaliação de políticas públicas em educação, Rio de Janeiro, v. 6, n. 19, p. 159-190, abr./jun. 1998.

EGIDO GALVEZ, I. Tres reformas educativas europeas: Reino Unido, Francia y España. Aspectos comparativos. Revista Española de Educación Comparada, Madrid, n. 3, p. 215-246, 1997.

EISEMON, T. O. Reducing repetition: issues and strategies. Paris: UNESCO, International Institute for Educational Planning, 1997.

ESPÓSITO, Y. L.; DAVIS, C.; NUNES, M. M. R. Avaliação de sistemas de ensino: do levantamento de índices à descrição de habilidades: um estudo da $5^{a}$ série. Em Aberto, Brasilia, DF, v. 17, n. 71, p. 100-128, jan. 2000.

FERRÃO, M. E.; BELTRÃO, K.; SANTOS, D. P. Impacto das políticas de não-repetência no desempenho acadêmico dos alunos da $4^{a}$ série: modelagem multinível. Rio de Janeiro: [s.n.], 2002.

FREHESE, E. Democratização em xeque? vicissitudes da progressão continuada no ensino paulista em 1999. 2001. Dissertação (Mestrado em Sociologia da Educação)-Universidade de São Paulo, São Paulo, 2001.

FREITAS, E. J. L. A implementação da política pública escola plural: as representações sociais dos pais sobre seus princípios de avaliação. 2000. Dissertação (Mestrado em Educação)-Universidade Federal de Minas Gerais, Belo Horizonte, 2000.

FREITAS, L. C. Ciclos de progressão continuada: vermelho para as políticas públicas. Eccos: revista científica, São Paulo, v. 4, n. 1, p. 79-93, 2002. 
GOMES, C. A. Desseriação escolar: alternativa para o sucesso? Brasília, DF: UNESCO, MEC, UCB, 2003.

A educação em perspectiva sociológica. 4. ed. São Paulo: EPU, 2005.

Educação no Brasil e no Leste Asiático: por que os contrastes? Universa, Brasília,

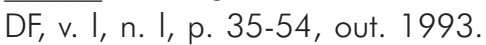

GOMES, C. A. Quinze anos de ciclos no ensino fundamental: um balanço das pesquisas sobre a sua implantação. Revista Brasileira de Educação, Rio de Janeiro, n. 25, p. 39-52, jan./abr. 2004.

GUIMARÃES, M. N. N. Práticas pedagógicas em época de progressão continuada: um olhar sobre a avaliação. 2001. Dissertação (Mestrado em Educação)-Universidade Federal de São Carlos, São Carlos, SP.

INSTITUTO NACIONAL DE ESTUDOS E PESQUISAS EDUCACIONAIS. Relatório síntese de divulgação dos resultados: SAEB 2001. Brasília, DF, 2002.

. SAEB/95: relatório final. Brasília, DF, 1998.

. SAEB/97: estudo comparativo dos resultados do SAEB 1995/1997. Brasília, DF, 1997.

KLEIN, R. Por uma educação de qualidade. Ensaio: avaliação de políticas públicas em educação, Rio de Janeiro, v. 11, n. 38, p. 115-120, jan./mar. 2003.

LANDSHEERE, G. A pilotagem dos sistemas de educação: como garantir a qualidade da educação? Porto, PT: Asa, 1997.

LIMA, A. I. B. A professora alfabetizadora: caminhos e descaminhos na construção de uma identidade. 1995. Dissertação (Mestrado em Educação)-Universidade Federal do Ceará, Fortaleza, 1995.

MAMEDE, I. C. M. Professoras alfabetizadoras: quem são, o que pensam e como alfabetizam. 2000. Tese (Doutorado em Educação)-Universidade Federal do Ceará, Fortaleza, 2000.

MELLO, G. N. A reforma do ensino primário e secundário na Inglaterra. São Paulo: Fundação para o Desenvolvimento Administrativo, Instituto de Economia do Setor Público, 1993. 
NAGATA, T. Entrevista pessoal com Prof. Dr. Tatsuya Nagata. Brasília, DF: Universidade Católica de Brasília, 20 out. 2002.

OAKES, J.; LIPTON, M. Making the best of schools: a handbook for parents, teachers, and policymakers. New Haven: Yale University Press, 1990.

OlIVEIRA, J. B. A. A pedagogia do sucesso. São Paulo: Saraiva: Instituto Ayrton Senna, 1998.

OLIVEIRA, Z. M. R. Avaliação da aprendizagem e progressão continuada: bases para construção de uma nova escola. Estudos em Avaliação Educacional, São Paulo, n. 18, p. 7-11, jul./dez. 1998.

ORIVEL, E.; ORIVEL, F. Les comparaisons internationales de l'efficience interne des systèmes éducatifs. In: PAUL, J. J. (Org.). Administrer, gérer, évaluer les systèmes éducatifs: une encyclopédie pour aujourd'hui. Paris: ESF, 1999,

p. 185-214.

PARANÁ. Secretaria de Estado da Educação. AVA 2000: relatório técnico: análise do desempenho da prova em função das características do aluno e da prova: $4^{a}$ série. Curitiba, PR: SEED, 2001 a.

AVA 2000: relatório técnico: análise do desempenho da prova em função das características do aluno e da prova: $8^{a}$ série. Curitiba, PR: SEED, 2001 b.

PARO, V. H. Por que os professores reprovam: resultados preliminares de uma pesquisa. Ensaio: avaliação e políticas públicas em educação, Rio de Janeiro, v. 8, n. 28, p. 273 282 , jul./set. 2000.

. Reprovação escolar: renúncia à educação. São Paulo: Xamã, 2001.

PIQUÉE, C.; SUCHAUT, B. Élements d'analyse de l'efficacité pédagogique du dispositif ARTE (Aide à la Réussite de Tous les Élèves). Dijon: IREDU-CNRS, Université de Bourgogne, 2002. Disponível em:

<http://www.u-bourgogne.fr/IREDU/2002/02091.pdf>. Acesso em: 17 maio 2003.

PLACCO, V. M. N. S.; ANDRÉ, M. E. D. A.; ALMEIDA, L. R. Estudo avaliativo das classes de aceleração na rede estadual paulista. Cadernos de Pesquisa, São Paulo, n. 108, p. 4979, nov. 1999. 
REIMERS, F. Conclusions: can our knowledge change what low-income children learn? In: . (Org.). Unequal schools, unequal chances: the challenges to equal opportunity in the Americas. Cambridge, Mass.: Harvard University, David Rockefeller Center for Latin American Studies, 2000. p. 431-451.

RIST, R. Student social class and teacher expectations: the self-fulfilling prophecy in ghetto education. Harvard Educational Review, Cambridge, Mass., v. 40, n. 3, p. 411-451, ago. 1970.

ROCHA, A. D. C. Contribuição das revisões de pesquisa internacionais ao tema evasão e repetência no $1^{\circ}$. grau. Cadernos de Pesquisa, São Paulo, n. 45, p. 57-65, maio 1983.

RODRIGUEZ, A. M. R. Avaliação do ensino por ciclos de formação: currículo, pedagogia e avaliação na perspectiva de professoras engajadas de uma escola municipal. 2002. Dissertação (Mestrado em Educação)-Universidade Federal do Rio Grande do Sul, Porto Alegre, 2002.

SAMPAIO, M. M. F. Aceleração de estudos: uma intervenção pedagógica. Em Aberto, Brasília, DF, v. 17, n. 71, p. 57-73, jan. 2000.

SCHEERENS, J. Improving school effectiveness. Paris: UNESCO-IIEP, 2000.

SCHEERENS, J.; BOSKER, R. The foundations of educational effectiveness. Oxford: Pergamon, 1997.

SCHIEFELBEIN, E.; SIMMONS, J. Os determinantes do desempenho escolar: uma revisão de pesquisas nos países em desenvolvimento. Cadernos de Pesquisa, São Paulo, n. 35, p. 53-72, nov. 1980.

SILVA, M. S. P.; MELLO, F. C. M. Políticas para enfrentamento do fracasso escolar: uma análise da proposta Escola Plural de Belo Horizonte. In: REUNIÃO ANUAL DA ANPED, 24., 2001, Caxambu, MG. Disponível em: <www.anped.org.br/24/P0568099736774.doc>. Acesso em: mar. 2005.

SNOW, C.; BURNS, M. S.; GRIFFIN, P. (Org.). Preventing reading difficulties in young children. Washington, DC: National Academy Press, 1998.

SOUSA, C. P. Limites e possibilidades dos programas de aceleração de aprendizagem. Cadernos de Pesquisa, São Paulo, n. 108, p. 81-99, nov. 1999. 
SOUSA, S. Z. et al. Ciclos e progressão escolar: indicações bibliográficas. Ensaio: avaliação e políticas públicas em educação, Rio de Janeiro, v. 11, n. 38, p. 99-114, jan./mar. 2003.

SOUZA, E. G. M. Classes de aceleração da aprendizagem em Campo Grande, MS. Em Aberto, Brasília, DF, v. 17, n. 71, p. 149-151, jan. 2000.

VASCONCELLOS, C. S. Ciclos de formação: um horizonte libertador para a escola no $3^{\circ}$ milênio. Revista de Educação AEC, Brasília, DF, n. 111 , p. 83-95, 1999.

VELLOSO DE SANTISTEBAN, A. El sistema educativo en Japón. Barcelona: Labor, 1994.

VIANNA, H. M. Desempenho dos alunos do ciclo básico de alfabetização em Minas Gerais: análise dos resultados e identificação de pontos críticos. Estudos em Avaliação Educacional, São Paulo, n. 6, p. 43-62, jul./dez. 1992.

WINKLER, D. Educating the poor in Latin América and the Caribbean: examples of compensatory education. In: REIMERS, F. (Org.). Unequal schools, unequal chances: the challenges to equal opportunity in the Americas. Cambridge, Mass.: Harvard University, David Rockefeller Center for Latin American Studies, 2000. p. 431-451.

WITTEK, N. Ley General de Educación Escolar de Suecia: reformas en la enseñanza media. Revista Española de Educación Comparada, Madrid, n. 3, p. 295-318, 1997.

\section{Correspondência:}

clgomes@terra.com.br 